Čolić, S., Nikolić, M., Čolić, V. (2020): The first record of blackfish, Centrolophus niger (Gmelin, 1788) in Montenegrin coastal waters. Agriculture and Forestry, 66 (2): 237-239.

(Short communication)

DOI: 10.17707/AgricultForest.66.2.21

Srećko ČOLIĆ' , Marko NIKOLIĆ ${ }^{2}$, Vukosava ČOLIĆ

\title{
THE FIRST RECORD OF BLACKFISH, Centrolophus niger (GMELIN, 1788) IN MONTENEGRIN COASTAL WATERS
}

\section{SUMMARY}

Here we report on the first finding of blackfish (Centrolophus niger) in the Montenegrin waters. On February 14th, 2018, in the Verige strait, on the locality Kamenari $\left(42^{\circ} 46.990^{\prime} \mathrm{N}, 018^{\circ} 67.852^{\prime} \mathrm{E}\right)$ two juvenile individuals were caught by gillnet. Their standard body length (SL) were 28.5 and $28.1 \mathrm{~cm}$, respectively.

Keywords: new record, fish, Centrolophus niger, Kamenari locality, Montenegrin coast.

\section{MAIN TEXT}

Blackfish, Centrolophus niger (Gmelin, 1788), is an epipelagic to mesopelagic fish species belonging to Centrolophidae family. Unlike adult individuals, the juvenile individuals live in the shallower waters, often in the surface layers. It is distributed in Atlantic, Indian, and Pacific Ocean. In the Mediterranean, it is mostly distributed in its western and central part (Jardas, 1996). In the eastern part of the Adriatic Sea, the blackfish is considered rare and little-known fish species (Dulčić and Lipej 2002). In the Croatian part of the eastern Adriatic Sea, sporadic findings of this species have been reported in the following localities: island Vir, island Vis (Langhoffer, 1904), Rijeka Bay (Langhoffer, 1904; Zavodnik and Kovačić 2000), Blitvenica island (Karlovac, 1974; Milišić, 2007), island Lastovo (Jardas, 1996), Split port (Dulčić and Lipej 2002, Milišić 2007), Novigrad Sea (Matić-Skoko et al. 2007) and Dubrovnik (Milišić, 2007). A juvenile specimen has been found near the cape Stončica, on the Vis island (Karlovac, 1974), and on the same locality a larval specimen caught with the plankton net (Regner, 1982). The discovery of larval and juvenile stages suggest the spawning of this species takes place in the Adriatic Sea. On the February 14th 2018, in the Verige passage, on the Kamenari locality $\left(42^{\circ} 46.990^{\prime} \mathrm{N}, 018^{\circ} 67.852^{\prime} \mathrm{E}\right)$ (Figure 1) two juvenile individuals were caught

\footnotetext{
${ }^{1}$ Srećko Čolić (corresponding author: sreckocolic84@gmail.com), University of Belgrade, Faculty of Biology, Institute of Zoology. Studentski trg 16, 11000 Belgrade, SERBIA.

${ }^{2}$ Marko Nikolić, University of Novi Sad, Faculty of Sciences, Department of Biology and Ecology, Trg Dositeja Obradovića 2, 21000 Novi Sad, SERBIA.

${ }^{3}$ Vukosava Čolić, University of Banja Luka, Faculty of Natural Sciences and Mathematics, Mladena Stojanovića 2, 78000 Banja Luka, Republic of Srpska, BOSNIA AND HERZEGOVINA.

Notes: The authors declare that they have no conflicts of interest. Authorship Form signed online. 
with gillnet ( $30 \mathrm{~m}$ length and $2 \mathrm{~m}$ height), approx. 25 meters away from the coast at a depth of approx. $6 \mathrm{~m}$.

Figure 1. Locality where the individuals of Centrolophus niger have been collected

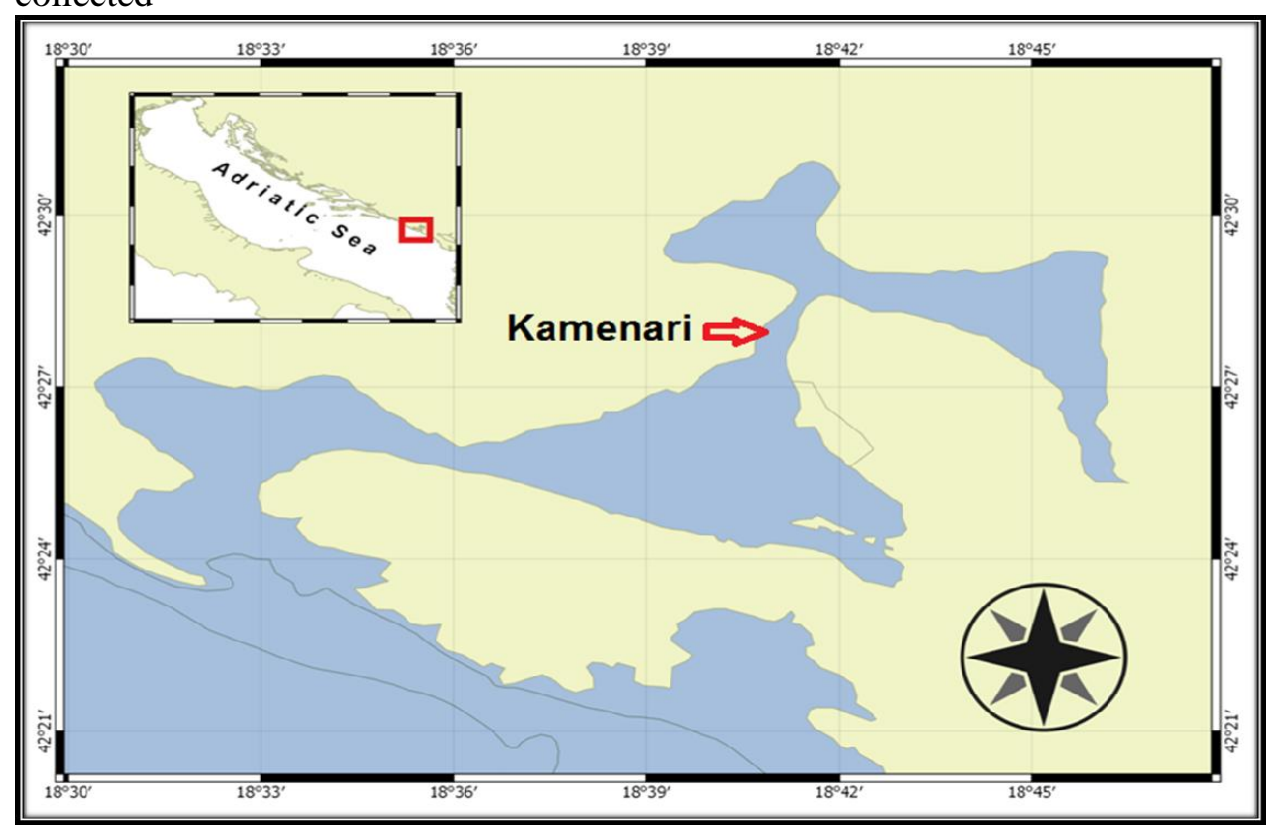

The specimens were identified following the key by Šoljan (1948, 1965), and preserved in $96 \%$ ethanol. Following measurements were obtained, respectively for each specimen: Standard length (SL) $28.5 \mathrm{~cm}$ and $28.1 \mathrm{~cm}$; total length (TL) $33.7 \mathrm{~cm}$ and $33.1 \mathrm{~cm}$, wight $390.8 \mathrm{~g}$ and $322.9 \mathrm{~g}$. The specimens had the following diagnostic characters: the first rays on the dorsal fin does not poke and the anus is located behind the tip of backward positioned pectoral fin. The tip of the backward positioned pectoral fin ends behind the tip of the backward positioned ventral fin. Along the rim of the lower back arch of the gill cover, there is a string of long, rigid and sharp teeth. Irregular light spots on the body of both individuals can be noticed (Figure 2), which indicates that they are juvenile specimens. Since this is a solitary fish type, the specificity of this finding is reflected in the fact that two individuals of the approximately same size were simultaneously caught at the same locality which confirms that this species may form small schools (Jardas, 1996). The stated is also being confirmed by the fact that the former findings were actually fishings of single individuals (Langhoffer, 1904; Karlovac, 1974; Jardas, 1996; Zavodnik and Kovačić, 2000; Dulčić and Lipej, 2002; Matić-Skoko et al. 2007; Milišić, 2007), except in the case of larvae sampling with the plankton net. This finding represents the first documented record of this species in the Montenegrin coastal waters. In the future, it is necessary to perform a systemic monitoring, with a purpose of determination of 
its constant presence and possible spawning areas, as well as the size of the areal of this rare species in the Montenegrin coast. Also, social networks may help efficiently share information about the occurrence and existence of rare ichtiological species at specific sites as long as there is a regular review of date in order to avoid taxonomic errors (Langeneck et al. 2017).

Figure 2. Centrolophus niger from Kamenari locality (Boka Kotorska Bay)

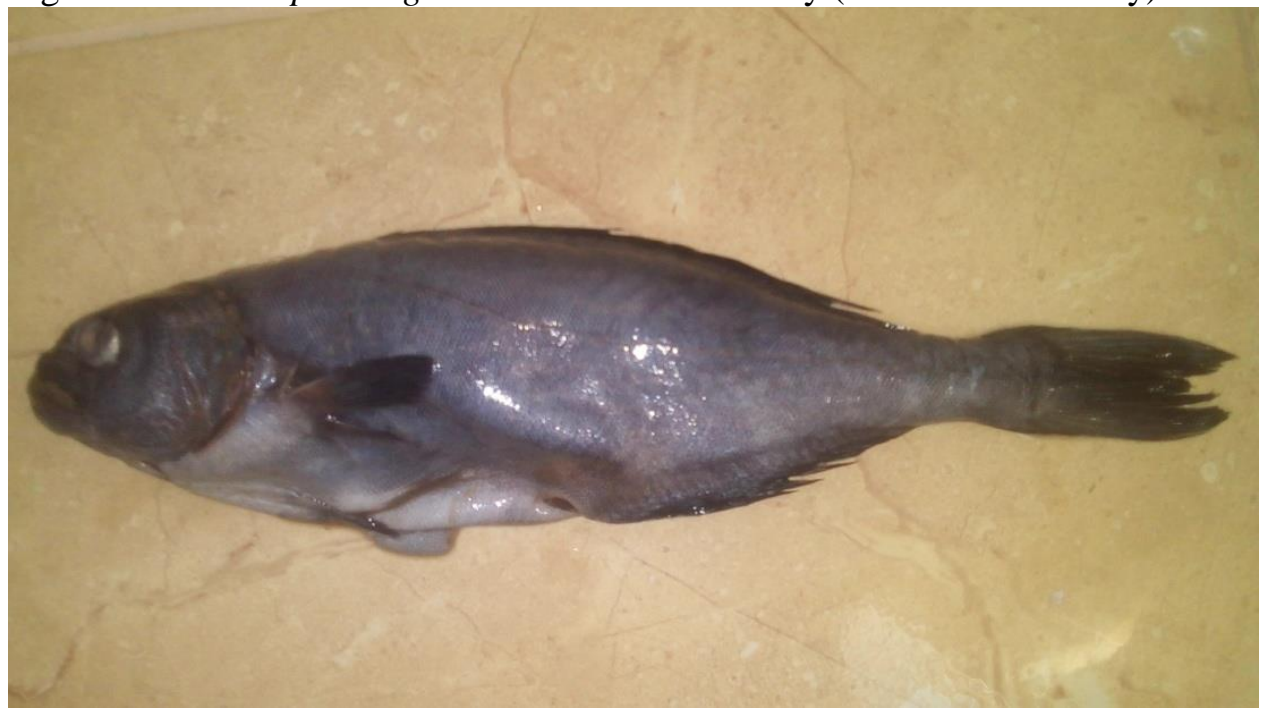

\section{REFERENCES}

Dulčić, J., Lipej, L. (2002): Rare and little-known fishes in the Eastern Adriatic during last two decades. Periodicum Biologorum, 104(2): 185-194.

Jardas, I. (1996): Jadranska ihtiofauna. Zagreb, Školska knjiga, 533 pp.

Karlovac, J. (1974): The juvenile stage of the species Centrolophus niger (Gmelin) found in the plankton of the middle Adriatic. Acta Adriatica, 32: 1-7.

Langhoffer, A. (1904): Popis riba, koje su prispjele narodnom zoološkom muzeju u Zagrebu do konca godine 1900. Glasnik hrvatskoga naravoslavnoga društva 16: $148-169$.

Langeneck, J., Marcelli, M., Bariche, M., Azzurro, E. (2017): Social networks allow early detection of non indigenousspecies: first record of the red drum Sciaenops ocellatus (Actinopterygii: Perciformes: Sciaenidae) in Italian waters. Acta Adriatica 58: 365-370.

Matić-Skoko, S., Peharda, M., Pallaoro, A., Cukrov, M., Baždarić, B. (2007): Infralittoral fish assemblages in the Zrmanja estuary, Adriatic Sea. Acta Adriatica 48: 45-55.

Milišić, N. (2007): Sva riba Jadranskog mora - drugi dio. Sveučilišna knjižnica u Splitu, $212 \mathrm{pp}$.

Regner, S. (1982): Istraživanja sastava i brojnosti larvalnih stadija riba u planktonu otvorenog mora srednjeg Jadrana. Studia Marina 11-12: 45-60.

Zavodnik, D., Kovačić, M. (2000): Index of marine fauna in the Rijeka Bay (Adriatic Sea, Croatia). Natura Croatica 9(4): 297-379.

Šoljan, T. (1948): Ribe Jadrana. Flora i fauna Jadrana 1. Institut za oceanografiju i ribarstvo. Zagreb, Nakladni zavod Hrvatske, $437 \mathrm{pp}$.

Šoljan, T. (1965): Ribe Jadrana (Pisces mari Adriatici). Treće, prerađeno i dopunjeno izdanje. Beograd, Zavod za izdavanje udžbenika SR Srbije, 428 pp. 